\title{
Molecular characterization of bacterial microbiota associated with infectious bovine keratoconjunctivitis in Michoacán, Mexico
}

\author{
Caracterización molecular de la microbiota bacteriana asociada con queratoconjuntivitis infecciosa \\ bovina en Michoacán, México
}

\section{Caracterização molecular da microbiota bacteriana associada à ceratoconjuntivite bovina infecciosa em Michoacán, México}

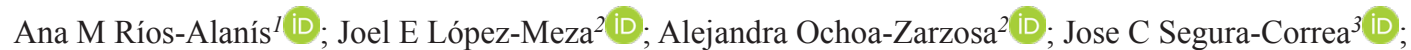 \\ José Herrera-Camacho ${ }^{1 *}$ iD.
}

\footnotetext{
${ }^{1}$ Instituto de Investigaciones Agropecuarias y Forestales. Universidad Michoacana de San Nicolás de Hidalgo. Morelia, Michoacán, México. ${ }^{2}$ Centro Multidisciplinario de Estudios en Biotecnología, Facultad de Medicina Veterinaria y Zootecnia, Universidad Michoacana de San Nicolás de Hidalgo. Morelia, Michoacán, México.

${ }^{3}$ Facultad de Medicina Veterinaria y Zootecnia. Universidad Autónoma de Yucatán. Mérida, Yucatán, México.
}

To cite this article:

Ríos-Alanis AM, López-Meza JE, Ochoa-Zarzosa A, Segura-Correa JC, Herrera-Camacho J. Molecular characterization of bacterial microbiota associated with infectious bovine keratoconjunctivitis in Michoacán, Mexico. Rev Colomb Cienc Pecu 2021; 34(1): 18-28. DOI: https://doi.org/10.17533/udea.rccp.v34n1a02

\section{Abstract}

Background: The most common ocular disease affecting cattle worldwide is infectious bovine keratoconjunctivitis (IBK), which has been associated with Moraxella bovis bacterium. Objective: To report the molecular characterization of the ocular bacterial microbiota and its relation to IBK in cattle in two dairy regions in Michoacán, Mexico. Methods: A total population of 761 bovines were evaluated, of which 17 (2.23\%) showed symptoms of IBK. Thirty-eight bacterial isolates from ocular samples of bovines with IBK were characterized by Gram-staining and antimicrobial sensitivity. In addition, isolates were identified by sequence comparisons of the $16 \mathrm{~S}$ ribosomal gene. Results: The genus Moraxella was one of the most abundant bacteria and $M$. bovoculi was the most predominant species. Conclusion: The bacterial isolates identified in eye lesions of cattle and associated to IBK are diverse. To the author's knowledge, this is the first study on the subject in Mexico; therefore, more research is needed to estimate the incidence of IBK and determine its associated microbiota.

Keywords: bacteria; bovine; corneal ulceration; dairy cattle; eye infection; IBK; keratoconjunctivitis; Moraxella bovis; Moraxella bovoculi; ocular bacteria; ocular disease; pink eye.

Received: March 3, 2020; accepted: June 3, 2020

*Corresponding Author. Km 9.5 Carretera Morelia-Zinapécuaro. Posta Veterinaria. C.P. 58880, Morelia, Michoacán, México. Email: josheca@hotmail.com 


\section{Resumen}

Antecedentes: la enfermedad ocular más común que afecta al ganado en todo el mundo es la queratoconjuntivitis infecciosa bovina (IBK), que se ha asociado con la bacteria Moraxella bovis. Objetivo: reportar la caracterización molecular de la microbiota bacteriana ocular y su relación con IBK en ganado de dos regiones lecheras en Michoacán, México. Métodos: se evaluó una población total de 761 bovinos de los cuales 17 (2,23\%) mostraron síntomas de IBK. Se obtuvieron treinta y ocho aislamientos bacterianos de muestras oculares de bovinos con IBK, los cuales se caracterizaron por tinción de Gram y sensibilidad antimicrobiana. Además, los aislamientos se identificaron mediante comparaciones de secuencias del gen ribosomal 16S. Resultados: el género Moraxella fue una de las bacterias más abundantes y M. bovoculi fue la especie más predominante. Conclusión: los aislamientos bacterianos identificados en lesiones oculares de bovinos y asociados a IBK son diversos. Hasta donde sabemos, este es el primer estudio sobre el tema realizado en México; por lo tanto, es necesario ampliar esta investigación para estimar la incidencia de IBK y determinar la microbiota asociada con la misma..

Palabras clave: bacterias; bacterias oculares; bovinos; conjuntivitis; enfermedad ocular; ganado lechero; infección ocular; Moraxella bovis; Moraxella bovoculi; queratoconjuntivitis; ulceración corneal.

\section{Resumo}

Antecedentes: a doença ocular mais comum que afeta o gado no mundo é a ceratoconjuntivite bovina (IBK), que tem sido associada à bactéria Moraxella bovis. Objetivo: relatar a caracterização molecular da microbiota bacteriana ocular e sua relação com a IBK em bovinos de duas regiões leiteiras de Michoacán, México. Métodos: foi avaliada uma população total de 761 bovinos, mas apenas 17 (2,23\%) apresentaram sintomas de IBK. Trinta e oito isolados bacterianos de amostras de olho bovino com IBK foram caracterizados por coloração de Gram e sensibilidade antimicrobiana. Além disso, os isolados foram identificados por comparação de sequências do gene ribossômico 16S. Resultados: a microbiota bacteriana associada à IBK foi diversa, sendo o gênero Moraxella uma das mais abundantes e $M$. bovoculi a espécie predominante. Conclusão: de acordo com o conhecimento dos autores, este é o primeiro estudo sobre o tema no México até o momento, portanto é necessário expandir essa pesquisa para estimar a incidência de IBK e determinar a microbiota associada à mesma.

Palavras-chave: bactérias; bactéria ocular; bovinos; ceratoconjuntivite, conjuntivite; doença ocular; gado leiteiro; infecção ocular; Moraxella bovis; Moraxella bovoculi; ulceração corneana. 


\section{Introduction}

Infectious bovine keratoconjunctivitis (IBK, also known as "pink eye") is a disease distributed worldwide and mainly associated to Gram-negative coccobacillus bacterium Moraxella bovis; but other agents such as $M$. ovis, Mycoplasma bovoculi, and Clamydophila spp., have also been implicated (Alexander, 2010). In addition, Moraxella bovoculi has been considered as a potential causal organism (Angelos et al., 2007; Sosa and Zunino, 2013).

Corneal ulceration caused by IBK often heals without therapeutic intervention and cattle generally recover; however, corneal rupture can result in complete and permanent loss of vision in severe cases, with marked ocular discomfort (Williams, 2010). Besides welfare implications, IBK also has a considerable economic impact, particularly due to reduced weight gain in calves suffering from IBK at weaning, and the cost of antibiotics (Schnee et al., 2015; Kowalski et al., 2017). Some studies have estimated losses of 10 to $20 \mathrm{~kg}$ of BW per infected animal. In the United States, 10 million cattle have this disease (Hare et al., 2008), causing losses of more than 200 million dollars per year (Addison, 2011).

In México, IBK is considered an enzootic disease, and it is associated to environmental conditions and seasonal vectors in some geographical regions. In the North of Mexico, the intense solar radiation is thought to be the most important factor favoring the presence of IBK. In the Central region of the country, it is associated with the presence of flyes and dusty winds, whereas in the South it is attributed to vectors (Gasque, 2008). The impact of this pathology in animal production in Mexico is unknown (Infante et al., 2000; Zamora et al., 2010).

Studies about the eye bacterial microbiota of healthy or diseased bovines are scarce. In addition, identification of microorganisms associated with IBK is required to establish if the clinical presentation is caused by secondary colonization of the damaged eye or if such microorganisms participate in the pathogenesis (Spradbrow, 1967; Handool, 2013; Sosa and Zunino, 2013). There is no information on the causal agent of IBK in Mexico; however, animals with eye lesions suggestive of IBK are frequently observed.

Therefore, the objective of this study was to report the molecular characterization of the ocular bacterial microbiota and their relation with IBK in cattle from two dairy regions in Michoacán, Mexico.

\section{Materials and Methods}

The study was carried out from July to December of 2015 in the localities of Uruétaro $\left(19^{\circ} 48^{\prime}\right.$ North latitude and $101^{\circ} 10^{\prime}$ West longitude, 1,860 m.a.s.1.), and Villa Madero (19 $59^{\prime}$ North latitude and $103^{\circ} 01^{\prime}$ West longitude, 2,000 m.a.s.1.) in the Morelia-Queréndaro Valley dairy region, and Marcos Castellanos (19 59' North latitude and $103^{\circ} 01^{\prime}$ West longitude, 2,000 m.a.s.1.), Sahuayo $\left(20^{\circ} 03^{\prime}\right.$ North latitude and $102^{\circ} 44^{\prime}$ West longitude, 1,530 m.a.s.1.), and Emiliano Zapata $\left(20^{\circ} \quad 01^{\prime}\right.$ North latitude and $102^{\circ} 36^{\prime}$ West longitude, 1,540 m.a.s.1.) in the Ciénega de Chapala dairy region in Michoacán, under a hot subhumid climate.

\section{Sampling}

Samples were collected from 17 bovines $(2.23 \%)$ showing ocular lesion, presumptive of IBK, from a population of 761 cattle. The animals were located in five localities and distributed in 11 herds. The number of affected animals and the number of herds sampled by locality were seven in Sahuayo (5 herds), four in Marcos Castellanos (3 herds), two in Uruétaro (1 herd), two in Emiliano Zapata (1 herd), and two in Villa Madero (1 herd). All were family herds under intensive (Uruétaro and Emiliano Zapata; 18.18\%), extensive (Villa Madero; 9.09\%), and semi-extensive systems (Sahuayo and Marcos Castellanos; 72.72\%).

The animals were placed in a cattle chute designed to minimize stress during eye inspection and sampling, and were observed for uni- or 
bilateral ocular symptoms suggestive of IBK. Before sampling, the periocular region of the eye was cleaned with a gauze soaked into a $10 \%$ benzalkonium chloride soap, and $0.9 \%$ sodium chloride solution. Samples were taken from the ventral area of the eye, between the ocular globe and the conjunctival sac, using a sterile cotton swab, and then kept in a tube with Cary-Blair sterile medium (Copan Italia SpA, Brescia, Italy) until processing.

\section{Culture of ocular samples}

Culture was conducted within a laminar flow hood. The collected conjunctival swab samples were streaked on blood agar plates and grown $24 \mathrm{~h}$ at $37^{\circ} \mathrm{C}$. After incubation, colonies were observed under a microscope. The size, shape, edge, area, color, and presence of hemolysis in the colonies was evaluated. The gray-whitish, round, small convex colonies, with or without a hemolysis halo that could be associated with Moraxella were selected. The isolates were infused into a $15 \mathrm{ml}$ Falcon tube containing 2.5 $\mathrm{ml}$ of Luria Bertani (LB) broth and incubated per $24 \mathrm{~h}$ at $37{ }^{\circ} \mathrm{C}$ under continuous stirring. One aliquot was mixed with $10 \%$ glycerol and stored at $-80 \mathrm{oC}$. The remaining sample was used to carry out the Gram-staining, antimicrobial testing, and DNA extraction.

\section{DNA extraction}

Samples of $1.5 \mathrm{ml}$ culture from bacterial isolates were grown overnight in LB broth. The suspension was used for DNA extraction by CTAB (hexadecyltrimethylammonium bromide) protocol (Minas et al., 2011). DNA was resuspended in deionized water and DNA integrity was verified by standard electrophoresis in $1 \%$ agarose gels.

\section{Identification of bacterial isolates}

In order to identify the bacterial isolates, a $1.5 \mathrm{~kb}$ fragment of the $16 \mathrm{~S}$ ribosomal gene was amplified by PCR. Forward 5-AGAGTTTGATCCTGGCTGAG-3 ${ }^{\circ}$ and reverse 5-GGTTCCTTGTTACGACTT-3 oligonucleotides (Elim Biopharmaceuticals,
Inc, Hayward, CA, USA) were used. PCR amplification was carried out using $50 \mathrm{ng}$ of DNA and the Platinum PCR SuperMix High Fidelity (Invitrogen, California, USA) in a final volume of $20 \mu \mathrm{l}$. The same mix was used without DNA as a negative control. The amplification reaction was performed under the following conditions: an initial step at $95{ }^{\circ} \mathrm{C}$ for $5 \mathrm{~min}$, and then 30 cycles of the program, $30 \mathrm{~s}$ at $95{ }^{\circ} \mathrm{C}$ for DNA denaturalization, $30 \mathrm{~s}$ at $58{ }^{\circ} \mathrm{C}$ for oligonucleotides alignment, and an extension at $72{ }^{\circ} \mathrm{C}$ for $1.5 \mathrm{~min}$. At the end of the final amplification, a one extension at 72 ${ }^{\circ} \mathrm{C}$ for $5 \mathrm{~min}$ was performed. The integrity of the PCR products was revised and analyzed by electrophoresis in 1\% agarose gels.

The PCR products were sequenced by Sanger technique by Elim Biopharmaceuticals, Inc (Hayward, CA, USA). The electropherograms were analyzed using the Mega 7.0.7 (DNASTAR) program. The sequences obtained from the bacterial $16 \mathrm{~S}$ gene were compared with those available in the NCBI data bank to identify the isolates using the BLAST option (https://www. ncbi.nlm.nih.gov/guide/sequence-analysis/).

\section{Antimicrobials tests}

All of the bacterial isolates were tested for antimicrobial susceptibility, which was determined using the disk diffusion method on Mueller-Hinton (MH) agar plates (Bioxon, Mexico). The following disks for Gram-negative bacteria (Gram Negatives II Bio-Rad) were used: amikacin, $30 \mu \mathrm{g}$; ampicillin, $10 \mu \mathrm{g}$; levofloxacin, $5 \mu \mathrm{g}$; cephalothin, $30 \mu \mathrm{g}$; cefotaxime, 30 $\mu \mathrm{g}$; ceftriaxone, $30 \mu \mathrm{g}$; chloramphenicol $30 \mu \mathrm{g}$; gentamicin, $10 \mu \mathrm{g}$; netilmicin 30 $\mu \mathrm{g}$; nitrofurantoin $300 \mu \mathrm{g}$; cefepime $30 \mu \mathrm{g}$; trimethoprim-sulfamethoxazole $25 \mu \mathrm{g}$. In addition, the following antimicrobials used against Gram-positive bacteria were evaluated (Gram-positive, Bio-Rad, México): ceftazidime, $30 \mu \mathrm{g}$; cefuroxime, $30 \mu \mathrm{g}$; dicloxacillin, $1 \mu \mathrm{g}$; erythromycin, $15 \mu \mathrm{g}$; pefloxacin, $5 \mu \mathrm{g}$; penicillin, $10 \mathrm{U}$; tetracycline, $30 \mu \mathrm{g}$. Isolates were classified as susceptible, intermediate and resistant according to the manufacturer's instructions. 
An MH agar plate without antimicrobials was used as a control treatment. Plates were incubated at $37^{\circ} \mathrm{C}$ for $24 \mathrm{~h}$.

\section{Statistical analysis}

Data were analyzed using descriptive statitsitics based on frequencies.

\section{Results}

Seven hundred and sixty-one bovines from two dairy regions in Michoacán (México) were analyzed. According to symptoms, 17 animals $(2.23 \%)$ showed IBK, mainly localized in one eye. Fifteen bovines showed unilateral lesions and only two showed lesions in both eyes. Based on the colony morphology, 38 colonies were isolated, of which 13 colonies were from samples of clinically healthy eyes, and 25 from cattle with morphological lesions (Table 1).

In a first approach, the bacterial isolates were identified using the Gram-staining. The results showed that $68.98 \%$ of the bacterial isolates were Gram-positive and 31.56\% were Gram-negative. Furtherly, bacterial isolates were identified using the sequences of the $16 \mathrm{~S}$ ribosomal RNA. In the Gram-positive samples, the most abundant bacterial microbiota corresponded to Staphylococcus saprophyticus (15.78\%), Staphylococcus agnetis (10.25\%), Streptococcus uberis (7.89\%), Staphylococcus chromogenes, and Arthrobacter luteolus (5.26\%). Staphylococcus haemolyticus, Streptococcus dysgalactiae, Streptococcus suis, Enterococcus mundtii, Bacillus aerius, Bacillus toyonensis, Bacillus pumilus, Rothia nasimurium, Arthrobacter gandavensis, Peptoniphilus indolicus, and Corynebacterium aquilae were present in $2.63 \%$, each species. In relation to the Gram-negative isolates, the most abundant species was Moraxella bovoculi $(10.52 \%)$, whereas the remaining identified microorganisms (Pseudomonas aeruginosa, Pseudomonas zhaodongensis, Mannheimia granulomatis, Acinetobacter schindler, Enterobacter mori, and Moraxella equi) showed frequencies of $2.63 \%$ (Table 2).
Antimicrobial sensitivity of bacteria isolates and their resistance patterns are shown in Table 3. Multi-resistance was observed for different groups of antibiotics. The $88.8 \%$ of isolates was resistant to dicloxacillin, $77.7 \%$ to ceftazidime, $55 \%$ to penicillin, $22.2 \%$ to tetracycline and ampicillin, and only one isolate was resistant to erythromycin.

The highest resistance rate of Gram-positive isolates was toward doxycycline $(75 \% ; 18 / 24)$, ceftazidime and penicillin $(54.1 \% ; 13 / 24)$. Interestingly, Staphylococcus isolates showed resistance mainly to ceftazidime, dicloxacillin, and penicillin. In the same way, isolates of Streptococcus uberis showed 100\% resistance to dicloxacillin. Regarding to the genus Arthrobacter, isolates showed 100\% resistance to penicillin, $66.6 \%$ to pefloxacin, and $33.3 \%$ to doxycycline. In addition, $A$. gandavensis showed resistance to cephalothin, ceftazidime, erythromycin, ampicillin, and doxycycline.

Seven Gram-negative isolates were observed, of which only $M$. granulomatis showed sensitivity to all antimicrobials. The remaining isolates showed resistance to antimicrobials with different patterns (Table 3). Noteworthy, $P$. aeruginosa (case 2) showed resistance to nitrofurantoin, chloramphenicol, ceftriaxone, ampicillin, trimiteprim sulfamethoxazole, cefotaxime, cephalothin and cefepime. Also, $P$. zhaodongenisis (case 6) only showed resistance to ampicillin and levofloxacin. Finally, E. mori (case 14), A. schindler (case 17), M. equi (case 8 ) and M. bovoculi (cases 5 and 11) showed resistance to ampicillin and cephalothin.

\section{Discussion}

Bacterial isolates from injured eyes were diverse and mainly Gram-positive (68.98\%), similar to other reports in bovines (Sosa and Zunino, 2013), and humans with conjunctivitis (Hernández and Quintero, 2003). Presence of Gram-positive bacteria could be attributed to its resistance to adverse and dry conditions because they contain a thick cell-wall, rich in peptidoglycan (Russell, 2003). For the Gram-negative bacteria, the predominant genus was Moraxella. 
Table 1. Microorganisms obtained from ocular samples of bovines with presumptive infectious keratoconjunctivitis (IBK) in Michoacán, Mexico.

\begin{tabular}{|c|c|c|c|c|c|}
\hline Animal & Type of lesion & Injured eye & Sampled eye & Sample ID & Identified microorganism \\
\hline \multirow{4}{*}{1} & \multirow{4}{*}{ Bilateral } & Right, left & Left & M1 & Staphylococcus saprophyticus \\
\hline & & Right, left & Left & M2 & Rothia nasimurium \\
\hline & & Right, left & Right & M3 & Staphylococcus saprophyticus \\
\hline & & Right, left & Right & M4 & Staphylococcus saprophyticus \\
\hline \multirow{2}{*}{2} & \multirow{2}{*}{ Unilateral } & Right & Left & M5 & Bacillus toyonensis \\
\hline & & Right & Left & M6 & Pseudomonas aeruginosa \\
\hline \multirow{2}{*}{3} & \multirow{2}{*}{ Unilateral } & Left & Right & M7 & Staphylococcus saprophyticus \\
\hline & & Left & Left & M8 & Staphylococcus saprophyticus \\
\hline \multirow{2}{*}{4} & \multirow{2}{*}{ Unilateral } & Left & Right & M9 & Staphylococcus saprophyticus \\
\hline & & Left & Right & M10 & Enterococcus mundtii \\
\hline \multirow{5}{*}{5} & \multirow{5}{*}{ Bilateral } & Right, left & Right & M11 & Staphylococcus agnetis \\
\hline & & Right, left & Right & M12 & Staphylococcus agnetis \\
\hline & & Right, left & Left & M13 & Moraxella bovoculi \\
\hline & & Right, left & Left & M14 & Moraxella bovoculi \\
\hline & & Right, left & Left & M15 & Streptococcus uberis \\
\hline \multirow{3}{*}{6} & \multirow{3}{*}{ Unilateral } & Right & Right & M16 & Mannheimia granulomatis \\
\hline & & Right & Right & M17 & Streptococcus uberis \\
\hline & & Right & Right & M18 & Streptococcus uberis \\
\hline \multirow{2}{*}{7} & \multirow{2}{*}{ Unilateral } & Right & Right & M19 & Arthrobacter luteolus \\
\hline & & Right & Left & M20 & Bacillus aerius \\
\hline \multirow{2}{*}{8} & \multirow{2}{*}{ Unilateral } & Right & Left & M21 & Moraxella equi \\
\hline & & Right & Right & M22 & Arthrobacter gandavensis \\
\hline 9 & Unilateral & Right & Left & M23 & Arthrobacter luteolus \\
\hline \multirow{2}{*}{10} & \multirow{2}{*}{ Unilateral } & Right & Left & M24 & Streptococcus dysgalactiae \\
\hline & & Right & Right & M25 & Peptoniphilus indolicus \\
\hline \multirow{2}{*}{11} & \multirow{2}{*}{ Unilateral } & Left & Left & M26 & Bacillus pumilus \\
\hline & & Left & Right & M27 & Moraxella bovoculi \\
\hline \multirow{2}{*}{12} & \multirow{2}{*}{ Unilateral } & Right & Left & M28 & Pseudomonas zhaodongensis \\
\hline & & Right & Right & M29 & Moraxella bovoculi \\
\hline \multirow{2}{*}{13} & \multirow{2}{*}{ Unilateral } & Left & Right & M30 & Staphylococcus agnetis \\
\hline & & Left & Left & M31 & Corynebacterium aquilae \\
\hline \multirow{3}{*}{14} & \multirow{3}{*}{ Unilateral } & Right & Right & M32 & Enterobacter mori \\
\hline & & Right & Right & M33 & Staphylococcus chromogenes \\
\hline & & Right & Left & M34 & Streptococcus suis \\
\hline 15 & Unilateral & Right & Right & M35 & Staphylococcus chromogenes \\
\hline \multirow{2}{*}{16} & IJnilo & Right & Right & M36 & Staphylococcus haemolyticus \\
\hline & Unilateral & Right & Right & M37 & Staphylococcus agnetis \\
\hline 17 & Unilateral & Right & Left & M38 & Acinetobacter schindler \\
\hline
\end{tabular}


In addition, more bacterial isolates were obtained from injured eyes in comparison with healthy eyes. This could be explained by the fact that defense mechanisms are affected in the injured cornea favoring the invasion of opportunist infectious agents.

One of the main predisposing factors for the presentation of IBK is the environment. A previous study by Takele and Zerihun (2000) in South-east Ethiopia showed an incidence of $2.10 \%$ IBK in local zebu and crossbreed dairy animals, which is similar to what was observed here. In that study, the researchers reported unilateral presentation in $85.5 \%$ of the cases, whereas bilateral infection was $14.5 \%$. In our study 88.2 and $11.76 \%$ of unilateral and bilateral afections were observed, respectively. Aditonally, in $80 \%$ of reported IBK cases $\mathrm{M}$. bovis has been isolated together with other bacteria such as Actinomyces piogenes, Staphylococcus aureus, Pasteurella haemolytica, Escherichia coli, and Proteus spp (Takele and Zerihun, 2000). In our study, the ocular bacterial microbiota was diverse, probably related with the environment and production system of each farm (intensive or semi-intensive), which may favor dissemination or growth of different bacteria populations. It is important to highlight that in this study, although we found presumptive symptomatology to IBK, this was associated with the presence of $M$. bovoculi and not to M. bovis as reported by Takele and Zerihun (2000). According to the above comments, it is necessary to conduct studies in Mexico's tropical areas to determine if M. bovis is the causal agent of IBK.

Studies in cattle where bacterial microbiota was identified show some of the species of bacteria reported here; i.e., Acinetobacter spp. (Wilcox, 1970; Hare et al., 2008; Sosa and Zunino, 2013), Bacillus spp., Corynebacterium (Spradbrow, 1967; Wilcox, 1970), Streptococcus ssp. (Sosa and Zunino, 2013), A. gandavensis, A. luteolus, Pseudomonas spp. (Hare et al., 2008, Sosa and Zunino, 2013), Arthrobacter (Sosa and Zunino, 2013), and M. bovoculi (Blood and Radostits, 1992; Angelos et al., 2007; Libardoni et al., 2007). Differences between studies could be attributed to geographical locations, which are expected to have different environmental conditions. In the same way, some of the bacteria isolated in this study have been associated with etiological agents of bovine conjunctivitis and bovine keratosis. However, other opportunistic bacteria living in the skin and nasal cavities are commonly found in the conjunctivae of the eyes of healthy animals (Handool, 2013), favored by farm environmental and management conditions.

Table 2. Frequency of bacterial isolates associated to presumptive infectious bovine keratoconjunctivitis (IBK) in catle in Michoacán, México.

\begin{tabular}{clc}
\hline Gram-classification & Microorganism & Frequency (\%) \\
\hline & Acinetobacter schindler, Pseudomonas aeruginosa, Mannheimia granulomatis, & \\
& Bacillus aerius, Pseudomonas zhaodongenisis, Corynebacterium aquilae, & 2.63 \\
Negative & Enterobacter mori. & 2.63 \\
& Moraxella equi & 10.52 \\
\hline & Moraxella bovoculi & 2.63 \\
& Rothia nasimurium, Bacillus toyonensis, Enterococcus mundtii, Arthrobacter & \\
& gandavensis, Streptococcus dysgalactiae, Peptoniphilus indolicus, Bacillus & 5.26 \\
& pumilus, Streptococcus suis, Staphylococcus haemolyticus. & 7.89 \\
Positive & Arthrobacter luteolus, Staphylococcus chromogenes & 10.52 \\
& Streptococcus uberis & 15.78 \\
\hline
\end{tabular}


Table 3. Antimicrobial sensitivity of isolates associated with infectious bovine keroconjuntivitis (IBK) in catle in Michoacán, México.

\begin{tabular}{|c|c|c|c|}
\hline Isolates & Clinical case & Location & Antimicrobial resistance pattern \\
\hline \multirow{7}{*}{ Staphylococcus saprophyticus } & 1 & Uruétaro & CAZ, DC, PE \\
\hline & 2 & Uruétaro & CAZ, E, DC, PE \\
\hline & 2 & Uruétaro & CAZ, E, DC, PE \\
\hline & 3 & Emiliano Zapata & $\mathrm{CAZ}, \mathrm{AM}, \mathrm{DC}, \mathrm{PE}$ \\
\hline & 3 & Emiliano Zapata & CAZ, TE, DC, PE \\
\hline & 4 & Emiliano Zapata & CAZ, TE, DC, PE \\
\hline & 5 & Villa Madero & $\mathrm{CAZ}, \mathrm{AM}, \mathrm{DC}, \mathrm{PE}$ \\
\hline \multirow{3}{*}{ Staphylococcus agnetis } & 5 & Villa Madero & $\mathrm{CAZ}$ \\
\hline & 13 & Sahuayo & CAZ, DC \\
\hline & 16 & Marcos Castellanos & $\mathrm{DC}$ \\
\hline Staphylococcus chromogenes & 15 & Marcos Castellanos & CAZ, DC \\
\hline \multirow{3}{*}{ Streptococcus uberis } & 5 & Villa Madero & $\mathrm{CAZ}, \mathrm{AM}, \mathrm{DC}, \mathrm{PE}$ \\
\hline & 6 & Villa Madero & DC \\
\hline & 6 & Villa Madero & $\mathrm{DC}$ \\
\hline \multirow{2}{*}{ Arthrobacter luteolus } & 7 & Sahuayo & PEF, PE \\
\hline & 9 & Sahuayo & PEF, DC, PE \\
\hline Arthrobacter gandavensis & 8 & Sahuayo & CF, CAZ, E, AM, DC, PE \\
\hline Rothia nasimurium & 1 & Uruétaro & CAZ, DC, PE \\
\hline Bacillus toyonensis & 2 & Uruétaro & CAZ, DC, PE \\
\hline Bacillus aerius & 7 & Sahuayo & CAZ, CTX, DC \\
\hline Bacillus pumilus & 11 & Sahuayo & CMX, DC \\
\hline Peptoniphilus indolicus & 10 & Sahuayo & $\mathrm{DC}, \mathrm{PE}$ \\
\hline Corynebacterium aquilae & 13 & Sahuayo & CF, CAZ, E, AM, PEF, DC, PE \\
\hline Pseudomonas & 2 & Uruétaro & $\begin{array}{c}\text { NF, CL, CRO, AM, STX, CTX, } \\
\text { CF, FEP }\end{array}$ \\
\hline aeruginosa & 12 & Sahuayo & $\mathrm{AM}, \mathrm{LEV}$ \\
\hline Pseudomonas zhaodongenisis & 14 & Marcos Castellanos & $\mathrm{AM}, \mathrm{CF}$ \\
\hline Enterobacter mori & 17 & Marcos Castellanos & $\mathrm{AM}, \mathrm{CF}$ \\
\hline \multirow[t]{2}{*}{ Acinetobacter schindler } & 8 & Sahuayo & $\mathrm{AM}, \mathrm{CF}$ \\
\hline & 5 & Villa Madero & $\mathrm{AM}, \mathrm{CF}$ \\
\hline \multirow[t]{2}{*}{ Moraxella equi } & 5 & Villa Madero & $\mathrm{AM}, \mathrm{CF}$ \\
\hline & 11 & Sahuayo & $\mathrm{AM}, \mathrm{CF}$ \\
\hline
\end{tabular}

CF: Cephalothin $30 \mu \mathrm{g}$, CAZ: Ceftazidime $30 \mu \mathrm{g}$, E: Erythromycin $15 \mu \mathrm{g}$, AM: Ampicillin $10 \mu \mathrm{g}$, TE: Tetracycline $30 \mu \mathrm{g}$, STX: Trimethoprim sulfamethoxazole $25 \mu \mathrm{g}$, CTX: Cefotaxime $30 \mu \mathrm{g}$, GE: Gentamicin $10 \mu \mathrm{g}$, CMX: Cefuroxime $30 \mu \mathrm{g}$, PEF: Pefloxacin $30 \mu \mathrm{g}$, DC: Dicloxacillin $1 \mu \mathrm{g}$, PE: Penicillin 10U. NF: Nitrofurantoin $300 \mu \mathrm{g}$, CL: Chloramphenicol $30 \mu \mathrm{g}, \mathrm{CRO}$ : Ceftriaxone $30 \mu \mathrm{g}$, FEP: Cefepime $30 \mu \mathrm{g}$, LEV: Levofloxacin $5 \mu \mathrm{g}$. 
Antimicrobial sensitivity tests showed that IBK-associated isolates possess extensive resistance to $\beta$-lactams, mainly penicillin, ampicillin, and doxycycline. Many Gramnegative bacteria have a naturally occurring chromosome-mediated $\beta$-lactamase that confers resistance to this group of antibiotics and the use of new $\beta$-lactams resistant to the hydrolytic action of $\beta$-lactamases has caused the emergence of new $\beta$-lactamases that favors resistance selection to those drugs (Bradford, 2001). Strains producing extended-spectrum beta-lactamases (ESBL), such as Gram-negative bacilli, mainly enterobacteria, are generally multi-resistant, especially betalactams. Bacterial resistance is also attributed to the common use of these drugs for the treatment of several infectious diseases in cattle (Ochoa et al., 2008). Presumably, the selective pressure derived from the use and abuse of new antibiotics has selected for new variants of $\beta$-lactamase. In this regard, multi-resistant isolates were observed. For example, isolates of the species A. gandavensis, $C$. aquilae and $P$. aeruginosa showed resistance to more than $50 \%$ of the tested antimicrobials. These resistance patterns are most often associated with the integration of new enzymes obtained by conjugation, transformation, or transduction (Navarro et al., 2010). Although this could explain the frequency of resistance observed to $\beta$-lactams in our study, molecular studies are needed to identify if they have this type of enzymes. Different resistance patterns may indicate the preferred use of antimicrobials to treat IBK in each region (Loy and Brodersen, 2014), and the bacterial microbiota associated with this pathology can be related to the frequency and pattern of use of antibiotics in dairy systems.

In conclusion, normal bacterial microbiota of the conjunctivae has been poorly studied, lacking phenotypic and genotypic indicators to compare the bacterial microbiota of the clinically healthy eye and animals with IBK. In this study, the bacterial isolates identified in eye lesions of cattle and associated to IBK was diverse. This is the first study on the subject conducted in Mexico. More studies on IBK are required under the conditions of Michoacán and other Mexican regions.

\section{Declarations}

\section{Acknowledgments}

To Consejo Nacional de Ciencia y Tecnología (México) for the scholarship awarded (No. 326686), and to Ana M Rios Alanis.

\section{Funding}

This work was supported by The Coordinación de la Investigación Cientifica (Research Program 2015/2016) of Universidad Michoacana de San Nicolás de Hidalgo (México).

\section{Conflicts of interest}

The authors declare that they have no conflicts of interest with regard to the work presented.

\section{Author contributions}

Ana M Rios-Alanis, conducted most of the experimental work to obtain her Master's degree in agricultural sciences. Joel E. López-Meza, adviced on the development of the experimental work and interpretation of molecular tests to identify bacterial isolates. Alejandra OchoaZarzosa, contributed with development of primers and determination of DNA sequences. Jose C Segura-Correa, contributed to the statistical analysis and revision of the manuscript. José Herrera-Camacho, thesis director of Rios-Alanis, wrote the manuscript.

\section{References}

Addison B. Research shows new emerging strain ofpinkeye.ProgressiveCattleman2011;5:22-23. https://addisonlabs.com/wp-content/ uploads/2016/02/CattlemanPinkeye.pdf

Alexander D. Infectious bovine keratoconjunctivitis: A review of cases in clinical practice. Vet Clin Food Anim 2010; 26:487-503.

DOI: https://doi:10.1016/j.cvfa.2010.09.006 
Angelos JA, Spinks PQ, Ball LM, George LW. Moraxella bovoculi sp. nov., isolated from calves with infectious bovine keratoconjunctivitis. Int J Syst Evol Microbiol 2007; 57:789-795. DOI: $\underline{\text { https://doi.org/10.1099/ijs.0.64333-0 }}$

Blood DC, Radostits OM. Enfermedades causadas por bacterias. En: Medicina Veterinaria. Séptima edición. Vol I. Madrid Interamericana. McGraw-Hill, 1992; 750-753.

Bradford P. A. Extended-spectrum beta-lactamases in the $21^{\text {st }}$ century: characterization, epidemiology, and detection of this important resistance threat. Clin Microbol Rev 2001; 14:933-951. DOI: https://doi.org/10.1128/CMR.14.4.933-951.2001

Gasque R. Queratoconjuntivitis infecciosa bovina. Enciclopedia Bovina. Enfermedades de los bovinos. Facultad de Medicina Veterinaria y Zootecnia-UNAM. www.fmvz.unam.mx/ fmvz/e bovina/ 2008. Fecha de consulta: 12 de enero 2015.

Handool H. Isolation and identification of some genera and species of bacteria and fungi from conjunctiva in cattle in Al-Diwaniya city. AL-Qadisiya J Vet Med Sci 2013; 12:55-62. DOI: https://doi.org/10.29079/vol12iss2art258

Hare WR, Hoyt PG, Hohn C, Higgins JA. Ribosomal RNA-based analysis of the bacterial flora from the conjunctivae of cattle with bovine keratoconjunctivitis (BKC). Vet Microbiol 2008; 131:358-368. DOI: https://doi.org/10.1016/j.vetmic.2008.04.018

Hernández P, Quintero G. Etiología bacteriana de infecciones oculares externas. Nova Publicación Científica 2003; 1:57-64. DOI: https://doi.org/10.22490/24629448.1056
Infante FM, Flores G, Falcón NA, Infante AF. Control de un brote de queratoconjuntivitis infecciosa bovina mediante el control de las moscas en estadio larvario. Med Vet 2000; 17:273-276. DOI: https://pdfs.semanticscholar.org/6810/9cc3 670cfcbf69cf0df258e2c46ebf9ae6bd.pdf? $\mathrm{ga}=2 \quad .21258299 .1286023369 .1582899306-$ $\underline{648624553.1559616002}$

Kowalski AP, Maboni G, Gressler LT, Espíndola JP, Balzan C, Tasca C, Guizzo JA, Conceição F R, Frandoloso R, de Vargas AC. Antigenic characterization of Moraxella bovis, Moraxella bovoculi and Moraxella ovis strains with potential use in vaccines. Vet Microbiol 2017; 210:56-63. DOI: http://dx.doi.org/10.1016/j.vetmic.2017.08.016

Libardoni F, Scherer Ch, Farias L, Vielmo A, Balzan C, Vargas A. Moraxella bovoculi in cases of infectious bovine keratoconjunctivitis in Rio Grande do Sul. Brazil. Pesq Vet Bras 2007; 32:743-746. DOI: https://doi.org/10.1590/S0100-736X2012000800011

Loy JD, Brodersen BW. Moraxella spp. isolated from field outbreaks of infectious bovine keratoconjunctivitis: a retrospective study of case submissions from 2010 to 2013. J Vet Diag Invest 2014; 26:761-768. DOI: https://doi.org/10.1177/1040638714551403

NCBI (National Center for Biotechnology Information). https://www.ncbi.nlm.nih.gov/ guide/sequence-analysis/. Fecha de consulta: diciembre 2016.

Minas K, McEwan N, Newbold CJ, Scott KP. Optimization of a high-throughput CTABbased protocol for the extraction of qPCRgrade DNA from rumen fluid, plant and bacterial pure cultures, FEMS Microbiology $\begin{array}{llll}\text { Letters } 2011 ; 325 & \text { (2)2:162-169. DOI: }\end{array}$ https://doi.org/10.1111/j.1574-6968.2011.02424.x

Navarro JM, Tormo A, Martínez-García E. Stationary phase in gram-negative bacteria, FEMS Microbiol Rev 2010; 34:476-495. DOI: https://doi.org/10.1111/j.1574-6976.2010.00213.x 
Ochoa A, Loeza P, Torres F, Loeza H, Mascot N, SánchezS,LópezJE.Antimicrobial susceptibility and invasive ability of Staphylococcus aureus isolates frommastitis from dairybackyard system. Antonie Leeuwenhoek 2008; 94:199-206. DOI: https://doi.org/10.1007/s10482-008-9230-6

Russell A. Bacterial outer membrane and cell wall penetration and cell destruction by polluting chemical agents and physical conditions. Sci Prog 2003; 86(4):283-311. DOI: https://doi.org/10.3184/003685003783238608

Schnee C, Heller M, Schubert E, Sachse K. Point prevalence of infection with Mycoplasma bovoculi and Moraxella spp. in cattle at different stages of infectious bovine keratoconjunctivitis. VetJ2015;203:92-96.DOI: https://doi.org/10.1016/j.tvjl.2014.11.009

Sosa V, Zunino P. Diversity of Moraxella spp. Strains recovered from infectious bovine Keratoconjunctivitis cases in Uruguay. J Infect Dev Ctries 2013; 7:819-824. DOI: https://doi.org/10.3855/jidc.3458
Spradbrow PB. A microbiological study of bovine conjunctivitis and Keratoconjunctivitis. Aus Vet J 1967; 43:55-58. DOI: https://doi.org/10.1111/j.1751-0813.1967.tb15063.x

Takele G, Zerihun A. Epidemiology of infectious keratoconjunctivitis in cattle in South-east Ethiopia. J. Vet. Med. A 2000; 47:169-173. DOI: https://doi.org/10.1046/j.1439-0442.2000.00274.x

Wilcox GE. Bacterial flora of the bovine eye with special reference to the Moraxella and Neisseria. Aust Vet J 1970; 46:253-256. DOI: https://doi.org/10.1111/j.1751-0813.1970.tb15771.x

Williams DL. Welfare issues in farm animal ophthalmology. Veterinary Clinics of North America: Food Anim Prac 2010; 26:427-435. DOI: https://doi.org/10.1016/j.cvfa.2010.08.005

Zamora QMA, Aguilar AJ, Sumano L. Eficacia clínica del florfenicol oftalmico vs florfenicol parenteral en el tratamiento de queratoconjuntivitis infecciosa bovina. Vet Méx 2010; 41:219-25. DOI: http://www.scielo.org.mx/scielo.php?script=sci arttext\&pid=S0301-50922010000300006 